\title{
Closed-Loop Supply Chains in Circular Economy Business Models
}

\author{
Maria Holgado 1[0000-0002-6019-9598] and Anna Aminoff 2[0000-0001-5418-1263] \\ ${ }^{1}$ University of Sussex Business School, Brighton BN1 9SL, UK \\ m. holgadodsussex.ac.uk \\ ${ }^{2}$ Hanken School of Economics, 00101 Helsinki, Finland \\ anna.aminoffehanken.fi
}

\begin{abstract}
With the emergence of the Circular Economy (CE) approach into business models, there is need for deeper understanding of resource loops activities and how current supply chains can support the development of emerging CE business models. However, there is still limited research addressing the conceptualization of closed loops in the supply chain literature. This work addresses this research gap and proposes a typology for closed-loops that is independent from the type of product under concern. Our findings suggest that there are two types of closed-loop supply chains in circular business models. Further work is envisaged to understand how companies can effectively develop their closed-loop supply chains as part of their transformation towards a more circular business model.
\end{abstract}

Keywords: Circular Economy, Closed-Loop Supply Chains, Business Models.

\section{Introduction}

The Circular Economy (CE) can be achieved through long-lasting design, maintenance, repair, reuse, remanufacturing, refurbishing, and recycling [1]. An extensive introduction of these new activities into current industrial systems may create positive environmental benefits while disrupting the way how currently organizations and supply chains work. In this regard, it is necessary to redesign current supply chains. The concept of closedloop supply chains (CLSCs) emerge as a response to this need to reinterpret supply chains within the CE. Research efforts frequently focus on closed loops at the end-of-life (EOL) of consumer products. However, closing the loop happens all along product life cycles and for other types of primary and secondary products. Interestingly, only few contributions try to differentiate different kinds of closed loops in supply chains. For example, Wells and Seitz [2] propose four types of closed loops - internal or within manufacture, post-business, postconsumer and post-society - and discuss different characteristics and challenges for each type. This limited analysis of closed loops invite for further research in this topic, especially as new CE practices and business models gain popularity in businesses.

In this work, we adopt a view of supply chains based on Carter et al. [3]'s proposal of considering supply chain linked to one product and one agent. Thus, we study cases referring to one type of product, the product at the origin of the loop, and one focal agent, the CE business. Taking the loop characteristics as starting point for analysis, we differentiate between CE cases involving a CLSC and an Open-Loop Supply Chain (OLSC) and eventually identify two types of CLSCs within CE business models.

CLSCs are at the core of CE business models; however, they have been mainly studied as separate research streams. Moreover, there have been limited efforts to clarify the relationship of CE and Sustainable Supply Chain Management (SSCM) literature and practice. With this in mind, the aim of this work is to investigate the conceptual connection between CLSCs and emerging CE business models. Our work contributes to advance the knowledge on CLSCs by proposing a set of closed-loop types within CE business models and deriving a conceptualization of CLSCs that is illustrated with real-life examples. This work will ultimately bring support to companies in the design of the CLSCs and CE business models. Thus, facilitating the uptake of these practices in current businesses. 


\section{Background}

The CE calls for a new relationship with products and materials, which is more labour intense and less resource intense [4]. Lacy and Rutqvist [5] explored how companies can benefit within the CE by 'creating value from waste'. They identified 'Recovery and Recycling' as a business model type within the CE, in which everything that used to be considered as waste is revived for other uses. They identified two variations within this model: the recovery of value from EOL products and the recovery of waste and by-products from a company's own production process and operations. The latter includes the concept of Industrial Symbiosis (IS) which refers to the output waste and underutilized flows of one organization being used as valuable and productive inputs for another organization [6][7]. In a typical organization, finding suppliers and customers of these materials is under the purview of supply chain management (SCM). Thus, to make an effective IS application and relationship, SCM is a prerequisite [8] [9].

According to Stahel [4], CE business models can be categorized in two groups: those fostering reuse and product life extension via repair, remanufacture, upgrades and retrofits; and those obtaining new resources from old products via recycling their materials. Recycling has not been considered a high-value solution as the material value is reduced during the recycling process. It is often energy-intense and not free of environmental impacts [10]. However, within the CE recycling is seen as an enabler of a cascaded use of resources, thus, facilitating multiple use phases with declining product or material value and diverting resources from landfill [11]. When recycling processes mean transforming the old product or material into something of higher value, it is named as 'upcycling' [5]. In this work, we adopt this conceptual differentiation between recycling and upcycling.

Creating new CE business models has been a subject of interest in academia for several years. In this regard, there is an interest for understanding the process of developing sound business models within the CE [12] [13]. Three mechanisms have been identified as basis for building business model strategies within the CE [14]: (1) Slowing resource loops, by extending or intensifying the utilization period of products, e.g. product-life extension through repair or remanufacturing; (2) Closing resource loops, by enhancing recycling practices, e.g. postconsumer plastics recycling; (3) Narrowing resource loops, by reducing the amount of resources per product.

The SSCM and the CE concepts are both overlapping and supplementing each other [15] [16]. Within this view the evolution of supply chains leads to an integrated approach considering both forward and reverse supply chains simultaneously, populated as CLSC [17]. Reverse supply chain includes activities dealing with value recovery of EOL products either by the original product manufacturer or a third party [15] [18] [19]. EOL products are collected from customers and the appropriated processes are then performed, such as repairing, disassembling, remanufacturing, recycling, and disposing of them in an environmentally sensitive manner [19]. It's worth to note a terminology discrepancy between the business model mechanisms and the supply chain literature. In fact, CLSC literature refers to repair and remanufacturing as a mechanism to close the loop of a specific product whereas the above CE business model literature considers repair and remanufacturing as part of 'slowing the loop'. This is an example of the fragmentation of the CE thinking across several research fields, as highlighted by De Angelis et al. [20] and calls for increasing efforts to develop a common understanding between fields. Some authors make a distinction between open-loop and closed-loop SCM [15]. In a closedloop cycle, a component will be reused or recycled for the same application, whereas in an open-loop view, the materials or components enter another application [21] [22]. CLSCs deal with taking back products from customers and returning them to the original manufacturer for the recovery of added value by reusing the whole product or part of it [19]. OLSCs involve materials recovered by parties other than the original producers who are capable of reusing these materials or products [21]. Often the line between closed loop and open loop approaches is a very thin one; moreover, the main purpose is recovering added value and avoiding waste, which is supported by reverse logistics activities [23].

\section{Research framework}

Our initial categorization of CE businesses considered the loops they are creating with their operations. We differentiate between industrial (upstream) activities and customer (downstream) activities. Both industrial and consumer goods markets are included in the customer activities depicted in the framework (see Fig. 1). Arrows represent the stages from where and to where the loop occurs. We define the 'loop origin' as the stage where 
the 'origin product' exits its current linear journey, and 'loop termination' as the stage where the 'new, transformed or treated product' is used and initiates its new lifetime. We identified 4 types of loops: (I) from precustomer waste stage to industrial activities, or 'I2I'; (II) from pre-customer waste stage to customer activities, or 'I2C'; (III) from post-customer waste stage to industrial activities, or 'C2I'; (IV) from post-customer waste stage to customer activities, or ' $\mathrm{C} 2 \mathrm{C}$ '. Loops 'I2I' and 'I2C' are related to the internal and post-business loops proposed by Wells and Seitz [2] while loops 'C2I' and 'C2C' are related to their post-business, post-consumer and post-society loops. This new approach served our categorization purposes which needed to be independent of the type of customer and the type of product involved in the loop. It represents a more holistic view of those CE business models, whose final products are sold equally in both industrial and consumer goods markets (e.g. cases 8 and 11). Our categorization provides a comparison of the loops themselves, and of the type of recovery activities, as independent as possible from product type and other contextual factors.

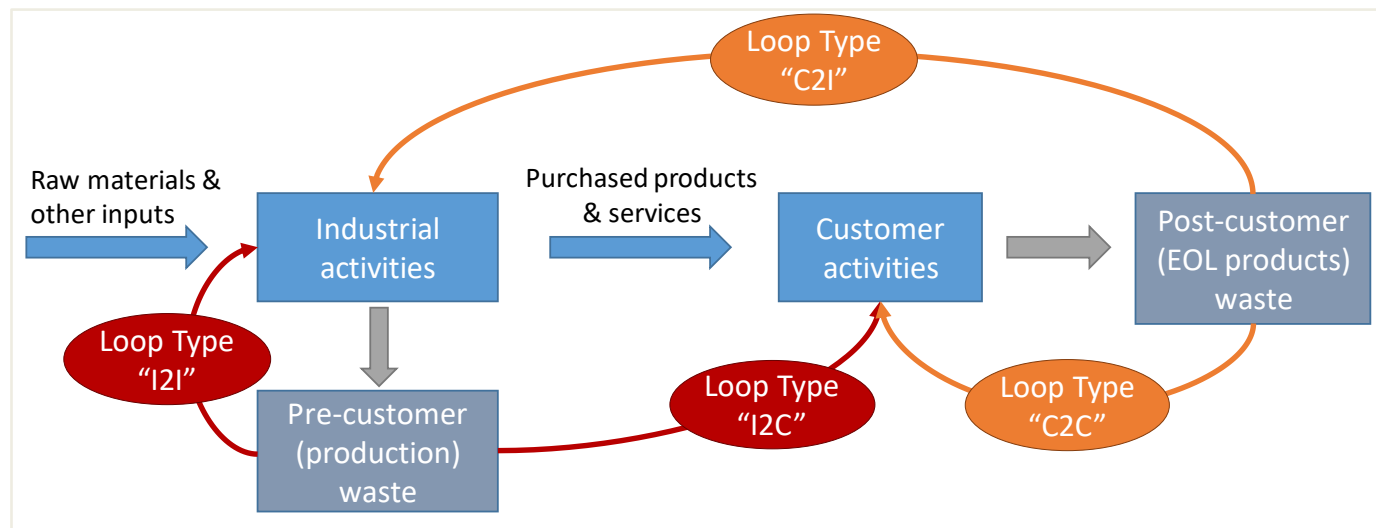

Fig. 1. Overview of the loops typology used to categorize the cases.

\section{Research design}

We have selected and analyzed 20 cases of supply chains in CE businesses, including exemplary cases from USA, Europe and China from a variety of sectors. The search for cases was done in repositories of case studies, sustainability-oriented blogs, news and in academic publications. The information available in those sources was complemented with information from the company website. Particularly, the repositories of cases studies used were those developed by the Ellen MacArthur Foundation ${ }^{1}$, The Remanufacturing Network ${ }^{2}$ and SITRA ${ }^{3}$. A variety of sectors were addressed in the selected cases, however, it seems worth remarking that most cases found, and therefore selected, are in the textile, fashion and clothing sectors (7 out of 20).

For all the cases, the product at loop origin was identified as well as the focal company. Data collection included information of supporting actors or partners mentioned in the case descriptions and company website, a high level description of the activities carried out to close the loop, the new product obtained at the end of the loop and, whenever applicable, the activities at the EOL of the new, transformed or treated product. Table 1 presents an overview of the cases.

\footnotetext{
${ }^{1}$ https://www.ellenmacarthurfoundation.org/case-studies

${ }^{2} \mathrm{https} / / /$ www.remanufacturing.eu/case-study-tool.php

${ }^{3} \mathrm{https}: / /$ www.sitra.fi/en/projects/interesting-companies-circular-economy-finland/
} 
Table 1. Overview of cases.

\begin{tabular}{|c|c|c|}
\hline $\begin{array}{l}\text { Case \# - Focal com- } \\
\text { pany, (country) }\end{array}$ & $\begin{array}{l}\text { Loop type (origin product to new, trans- } \\
\text { formed or treated product) }\end{array}$ & $\begin{array}{l}\text { Applica- } \\
\text { tion after } \\
\text { loop }\end{array}$ \\
\hline $\begin{array}{l}1-\text { Elvis \& Kresse } \\
\text { (UK) }\end{array}$ & $\mathrm{C} 2 \mathrm{C}$ (old firehoses to luxury accessories) & Different \\
\hline $\begin{array}{l}2-\text { Elvis \& Kresse } \\
\text { (UK) }\end{array}$ & I2C (leather cut-offs to luxury accessories) & Different \\
\hline 3 - Interface (USA) & $\mathrm{C} 2 \mathrm{C}$ (old fishing nets to carpet tiles) & Different \\
\hline 4 - Aquafil (Italy) & $\begin{array}{l}\text { C2I (nylon waste, incl. old fishing nets and } \\
\text { carpets to nylon yarn) }\end{array}$ & Same \\
\hline $\begin{array}{l}5 \text { - Purewaste (Fin- } \\
\text { land) }\end{array}$ & $\begin{array}{l}\text { I2C (textile production waste to new fabrics } \\
\text { and garments) }\end{array}$ & Different \\
\hline 6 - MUD Jeans (NL) & $\mathrm{C} 2 \mathrm{C}$ (old unusable jeans to new jeans) & Different \\
\hline 7 - Gazelle (USA) & $\begin{array}{l}\mathrm{C} 2 \mathrm{C} \text { (old electronics to certified refurbished } \\
\text { electronics) }\end{array}$ & Same \\
\hline 8 - Alisea (Italy) & I2C (graphite scrap to graphite pencil) & Different \\
\hline $\begin{array}{l}9 \text { - Guangzhou Huadu } \\
\text { (China) }\end{array}$ & $\begin{array}{l}\text { I2C (used transmission boxes to certified } \\
\text { spare parts) }\end{array}$ & Same \\
\hline 10 - MBS (Germany) & $\begin{array}{l}\mathrm{C} 2 \mathrm{C} \text { (used diesel engines to refurbished en- } \\
\text { gines) }\end{array}$ & Same \\
\hline 11 - Rype Office (UK) & $\mathrm{C} 2 \mathrm{C}$ (plastic waste to table tops) & Different \\
\hline $\begin{array}{l}12 \text { - Finlayson (Fin- } \\
\text { land) }\end{array}$ & $\mathrm{C} 2 \mathrm{C}$ (old linen sheets to rag rugs) & Different \\
\hline $\begin{array}{l}13 \text { - Finlayson (Fin- } \\
\text { land) }\end{array}$ & $\mathrm{C} 2 \mathrm{C}$ (old jeans to towels) & Different \\
\hline 14 - Niaga (NL) & $\mathrm{C} 2 \mathrm{C}$ (old carpets to new carpets) & Same \\
\hline 15 - Toast Ale (UK) & I2C (surplus bread to beer) & Different \\
\hline $\begin{array}{l}16 \text { - British Sugar } \\
\text { (UK) }\end{array}$ & $\begin{array}{l}\text { I2I (surplus CO2 and heat to glasshouse } \\
\text { plants) }\end{array}$ & Same \\
\hline 17 - Desso (NL) & $\mathrm{C} 2 \mathrm{C}$ (old carpets to new carpets) & Different \\
\hline $18-$ Fescon (Finland) & $\begin{array}{l}\text { I2I (blast furnace slag to fluidised bed mate- } \\
\text { rial for power plants) }\end{array}$ & Same \\
\hline $19-$ Ecoalf (Spain) & $\begin{array}{l}\mathrm{C} 2 \mathrm{C} \text { (PET bottles to garments and accesso- } \\
\text { ries) }\end{array}$ & Different \\
\hline 20 - Ecoalf (Spain) & $\mathrm{C} 2 \mathrm{C}$ (old tyres to flip flops) & Different \\
\hline
\end{tabular}

\section{Findings from the cases}

In this section, we present five observations from the cases and then present a conceptualization based on these observations.

Observation 1: The most common loop type found in the repositories is $C 2 C$.

This loop type closes the loop between post-customer wastes and customers activities. In contrast, it has been challenging to find cases of Loop type 'C2I'; the underlying reason might be that showing to public audiences a finished product is more appealing and engaging than intermediary industrial input material that create the finished product. For example, showing a recycled nylon yarn would attract less interest from the public than showing how the carpet tiles made with that yarn look in a finished carpeted floor. Loop type 'C2I' could be interpreted as an intermediary step of Loop type ' $\mathrm{C} 2 \mathrm{C}$ ' in some cases. For example, case 3 describes how Interface closes the loop by transforming old fishing nets into carpet tiles. For this, they collaborate with Aquafil that has the technology to make the actual transformation of nylon waste (from old fishing nets, among other sources) into nylon yarn, as described in Aquafil case. The nylon yarn is subsequently converted into carpet tiles in Interface case. Loop type 'I2I', that implicitly regards IS activities, was also less frequent in these online 
repositories. This might be explained similarly as loop type 'C2I'; both types concern industrial waste and activities.

Observation 2: The value recovery activities when products or material remains the same or is used in the same application are direct reuse (after some cleaning or inspection), refurbishment, remanufacturing and, in some occasions, also recycling. Table 2 provides an overview of the activities found in these cases. These cases are those that the SCM literature refers to as CLSCs.

Table 2. Overview of activities when the product / material remains the same.

\begin{tabular}{|c|c|c|}
\hline Case \# & What actions are performed within the loop? & $\begin{array}{l}\text { Activity cate- } \\
\text { gory }\end{array}$ \\
\hline 4 & $\begin{array}{l}\text { Depolymerisation and ECONYLC process, then } \\
\text { polymerization and yarn production }\end{array}$ & Recycling \\
\hline 7 & $\begin{array}{l}\text { Light refurbishment based on a } 30 \text { point functional and } \\
\text { cosmetic inspection }\end{array}$ & Refurbishment \\
\hline 9 & Disassembly and remanufacturing of parts & $\begin{array}{l}\text { Remanufactur- } \\
\text { ing }\end{array}$ \\
\hline 10 & $\begin{array}{l}\text { Disassembly, cleaning, change or refurbish parts as } \\
\text { needed, reassembly, painting }\end{array}$ & $\begin{array}{l}\text { Remanufactur- } \\
\text { ing }\end{array}$ \\
\hline 14 & $\begin{array}{l}\text { Separating material layers and using them to create new } \\
\text { carpets }\end{array}$ & Recycling \\
\hline 16 & Reuse directly for new purpose & Direct reuse \\
\hline 17 & $\begin{array}{l}\text { Separating yarn and fibres from the backing; the yarn } \\
\text { gets purified and returned to yarn manufacturer }\end{array}$ & Recycling \\
\hline 18 & Reuse directly for new purpose & Direct reuse \\
\hline
\end{tabular}

Observation 3: The value recovery activities when the product or material is transformed are either recycling or upcycling. In the cases in which the origin product / material is transformed it into a different product / material (here called transformed product) employ either recycling or upcycling as activities to perform the transformation. These cases are those that the SCM literature refers to as OLSCs. Further information was collected in these cases to understand what happens to the newly created products at their EOL. Table 3 provides an overview of the activities found in these cases regarding the transformation process and the EOL options.

The analysis of the cases brought up additional insights in terms of the role of recycling and CLSCs development in CE business models. Unlike other activities, recycling is used both when transforming the origin product into a different kind of product or material and when the origin product is recovered and used as the same product or material again. An example of the latter is the well-known activity of recycling glass bottles into new glass bottles that has been happening for decades in household waste management practices. In our cases, this can be observed in cases 4,14 and 17. Alternatively, recycling is a process used to transform a product or material into something different. This use is key to enable the cascading use of materials within CE business models, as described in cases included in Table 3.

Observation 4: The EOL of transformed products needs to be taken into consideration. The identification of the EOL activities for the transformed products coming out of OLSCs of the origin product, provides a more systemic view of system in which the transformed product is involved in its lifetime. We have found that companies initially performing activities such as recycling or upcycling in an OLSC for the origin product, often address the EOL of the new product as part of their business model. Alternatively, in some cases, the transformed product is recyclable by the same means again and again. In other cases, such as the graphite pencil or beer production, the new product will be fully consumed. We argue that these cases are enabling a CLSC for the new product, which is aligned to the cascaded used of resources and the CE.

These observations lead to the conceptualization of CLSCs in CE business models as shown in Fig. 2. Two types of CLSCs can be identified if we look holistically at both the product at the origin of the loop and the product at the termination of the loop. 
The first type regards the closed-loop of the origin product and involves different activities such as direct reuse, refurbishment, remanufacturing and recycling into the same material. This type is illustrated inside the yellow square in Fig. 2.

The second type concerns the closed-loop of the transformed product. While the initial transformation involves recycling and upcycling activities, the closed-loop of the transformed product (called 'new product' in Fig. 2) is afterwards performed by recovery processes such as direct reuse, refurbishment, remanufacturing and recycling into the same transformed product. This type is illustrated inside the orange square in Fig. 2.

Table 3. Overview of activities when the product / material is transformed.

\begin{tabular}{|c|c|c|c|}
\hline $\begin{array}{l}\text { Case } \\
\#\end{array}$ & $\begin{array}{l}\text { What actions are performed } \\
\text { within the loop? }\end{array}$ & $\begin{array}{l}\text { What happens at EOL } \\
\text { of new product? }\end{array}$ & $\begin{array}{l}\text { Activity category } \\
\text { within loop / at } \\
\text { EOL }\end{array}$ \\
\hline 1 & $\begin{array}{l}\text { Disassembly, cleaning and treat- } \\
\text { ment to make the material reusa- } \\
\text { ble }\end{array}$ & $\begin{array}{l}\text { Repair is offered to } \\
\text { customers }\end{array}$ & Upcycling / Repair \\
\hline 2 & $\begin{array}{l}\text { Cutting into small shapes to be } \\
\text { assembled to form the new prod- } \\
\text { uct }\end{array}$ & $\begin{array}{l}\text { Repair is offered to } \\
\text { customers }\end{array}$ & Upcycling / Repair \\
\hline 3 & $\begin{array}{l}\text { Using the ECONYL } @ \text { process } \\
\text { with partner Aquafil, then weav- } \\
\text { ing the yarn into tiles }\end{array}$ & $\begin{array}{l}\text { Product recyclable af- } \\
\text { ter use }\end{array}$ & $\begin{array}{l}\text { Recycling / Recy- } \\
\text { cling }\end{array}$ \\
\hline 5 & $\begin{array}{l}\text { Sorting by colour, refibering and } \\
\text { spinning into new yarn }\end{array}$ & $\begin{array}{l}\text { Product recyclable af- } \\
\text { ter use }\end{array}$ & $\begin{array}{l}\text { Recycling / Recy- } \\
\text { cling }\end{array}$ \\
\hline 6 & $\begin{array}{l}\text { Shredding old jeans, blending } \\
\text { with organic cotton to create new } \\
\text { pairs of MUD Jeans }\end{array}$ & $\begin{array}{l}\text { Product recyclable af- } \\
\text { ter use }\end{array}$ & $\begin{array}{l}\text { Recycling / Recy- } \\
\text { cling }\end{array}$ \\
\hline 8 & $\begin{array}{l}\text { graphite powder is moulded into } \\
\text { pencil shape; then attaching the } \\
\text { coloured eraser }\end{array}$ & $\begin{array}{l}\text { Product can be used } \\
\text { up completely }\end{array}$ & Recycling \\
\hline 11 & $\begin{array}{l}\text { Shredding plastic materials and } \\
\text { moulding then into table boards }\end{array}$ & $\begin{array}{l}\text { Repair and refurbish- } \\
\text { ment is offered to cus- } \\
\text { tomers }\end{array}$ & $\begin{array}{l}\text { Upcycling / Re- } \\
\text { pair, refurbishment }\end{array}$ \\
\hline 12 & $\begin{array}{l}\text { Washing linen, sewing together } \\
\text { and cutting into streams, then } \\
\text { winding and weaving them into } \\
\text { rag rugs }\end{array}$ & $\begin{array}{l}\text { Product recyclable af- } \\
\text { ter use }\end{array}$ & $\begin{array}{l}\text { Recycling / Recy- } \\
\text { cling }\end{array}$ \\
\hline 13 & $\begin{array}{l}\text { Crushing the jeans and spinning } \\
\text { the fibre into new yarn to be used } \\
\text { in towel production }\end{array}$ & $\begin{array}{l}\text { Product recyclable af- } \\
\text { ter use }\end{array}$ & $\begin{array}{l}\text { Recycling / Recy- } \\
\text { cling }\end{array}$ \\
\hline 15 & $\begin{array}{l}\text { Incorporating the surplus bread } \\
\text { into the brewing process to make } \\
\text { beer }\end{array}$ & $\begin{array}{l}\text { Product can be used } \\
\text { up completely }\end{array}$ & Upcycling \\
\hline 19 & $\begin{array}{l}\text { Cleaning and shredding plastic } \\
\text { bottles; then treatment and spin- } \\
\text { ning to obtain yarn }\end{array}$ & $\begin{array}{l}\text { Product recyclable af- } \\
\text { ter use }\end{array}$ & $\begin{array}{l}\text { Recycling / Recy- } \\
\text { cling }\end{array}$ \\
\hline 20 & $\begin{array}{l}\text { Separating rubber and turning it } \\
\text { into powder and then compress- } \\
\text { ing it without glue to create the } \\
\text { flip flops }\end{array}$ & $\begin{array}{l}\text { Product recyclable af- } \\
\text { ter use }\end{array}$ & $\begin{array}{l}\text { Recycling / Recy- } \\
\text { cling }\end{array}$ \\
\hline
\end{tabular}




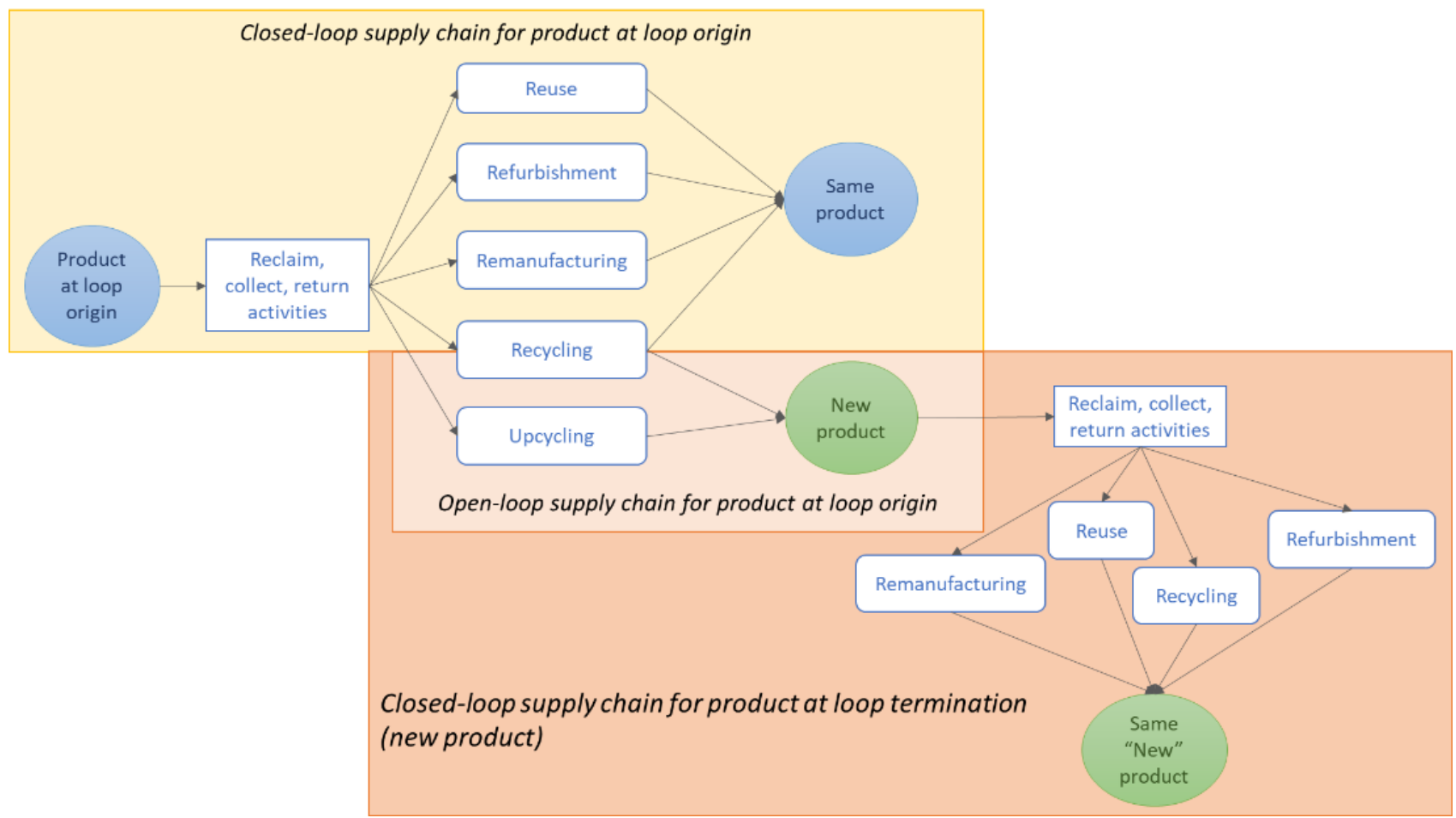

Fig. 2. Closed-loop supply chains in circular economy business models.

\section{Concluding remarks}

Previous studies have referred to the potential connection and synergies between CE and SCM topics [16] [24] [25], however their conceptual linkages are not explored in depth. This work brings together CE and SCM fields by studying the concept of closing the loop in CE business models. We adopted the view of supply chains linked to one product and one agent [3], we differentiated between recycling and upcycling activities and focused on slowing and closing mechanisms for the development of CE business models. We studied 20 cases of circular supply chains and draw two main contributions from the analysis. First, we developed the loop typology that, independently of the type of product, models the loop origin and termination according to production and consumption perspectives (Fig. 1). This brings a higher level of abstraction to the conceptualization of closed-loops and does not constraint the CE efforts to a particular market. Indeed, companies like Rype Office (case 11) serve their transformed products to both other businesses and consumers. This typology represents an attempt to overcome the issues brought up by Wells and Seitz [2] regarding difficulties in theory-building and generalizability due to closed loop characteristics being highly conditional on product type and contextual factors. Second we identified two different types of CLSCs within CE business models; those that close the loop for the origin product and those that close the loop for the transformed product, after the transformation happens within an OLSC of the origin product. In contrast with current complex / extensive typologies of business models (see [26] [27]), this differentiation brings a more holistic, while simplified, view of the system in which resources are kept and regenerated in the CE. These two conceptualizations might help future research on understanding the supply chain implications of CE business models.

By advancing the knowledge on CLSCs, this work provides support to improve scalability and replicability of CE business models which are key aspects limiting the wider implementation of CE in businesses [28]. Thus, further research will address how this conceptualization can lead to a supporting decision making tool to facilitate the development of CLSCs and their integration in current business models and operations.

\section{References}

1. Geissdoerfer, M., Savaget, P., Bocken, N. M., Hultink, E. J.: The Circular Economy-A new sustainability paradigm?. Journal of cleaner production, 143, 757-768 (2017).

2. Wells, P., Seitz, M.: Business models and closed-loop supply chains: a typology. Supply Chain Management: An International Journal, 10(4), 249-251 (2005). 
This is a pre-copyedited version of a contribution published in Sustainable Design and Manufacturing 2019. KES-SDM 2019. Smart Innovation, Systems and Technologies, Ball P., Huaccho Huatuco L., Howlett R., Setchi R. (eds), published by Springer, Singapore. The definitive authenticated version is available online via https://doi.org/10.1007/978-981-13-9271-9_19

3. Carter, C. R., Rogers, D. S., Choi, T. Y.: Toward the theory of the supply chain. Journal of Supply Chain Management, 51(2), 89-97 (2015).

4. Stahel, W. R.: The circular economy. Nature News, 531(7595), 435 (2016).

5. Lacy, P., Rutqvist, J.: Waste to Wealth: The Circular Economy Advantage, 1st ed., Palgrave Macmillan UK (2015)

6. Chertow, M. R.: "Uncovering” industrial symbiosis. Journal of Industrial Ecology, 11(1), 11-30 (2007).

7. Zhu, Q., Lowe, E. A., Wei, Y. A., Barnes, D.: Industrial symbiosis in China: a case study of the Guitang Group. Journal of Industrial Ecology, 11(1), 31-42 (2007).

8. Côte, R. P., Lopez, J., Marche, S., Perron, G. M., Wright, R.: Influences, practices and opportunities for environmental supply chain management in Nova Scotia SMEs. Journal of Cleaner Production, 16(15), 1561-1570 (2008).

9. Tudor, T., Adam, E., Bates, M.: Drivers and limitations for the successful development and functioning of EIPs (ecoindustrial parks): A literature review. Ecological Economics, 61(2-3), 199-207 (2007).

10. Allwood, J. M.: Squaring the circular economy: The role of recycling within a hierarchy of material management strategies. In Handbook of Recycling, pp. 445-477 (2014).

11. Ellen MacArthur Foundation: Towards the Circular Economy II: Opportunities for the con-sumer goods sector. Available at: www.ellenmacarthurfoundation.org/business/reports (2013).

12. Antikainen, M., Valkokari, K.: A framework for sustainable circular business model innovation. Technology Innovation Management Review, 6(7) (2016).

13. Linder, M., Williander, M.: Circular business model innovation: inherent uncertain-ties. Business Strategy and the Environment, 26(2), 182-196 (2017).

14. Bocken, N. M., de Pauw, I., Bakker, C., van der Grinten, B.: Product design and business model strategies for a circular economy. Journal of Industrial and Production Engineer-ing, 33(5), 308-320 (2016).

15. Genovese, A., Acquaye, A. A., Figueroa, A., Koh, S. L.: Sustainable supply chain manage-ment and the transition towards a circular economy: Evidence and some applica-tions. Omega, 66, 344-357 (2017).

16. Liu, J., Feng, Y., Zhu, Q., Sarkis, J.: Green supply chain management and the circular economy: Reviewing theory for advancement of both fields. International Journal of Physi-cal Distribution \& Logistics Management, 48(8), 794-817 (2018).

17. Guide Jr, V. D. R., Van Wassenhove, L. N.: OR FORUM-The evolution of closed-loop supply chain research. Operations research, 57(1), 10-18 (2009).

18. Zhu, Q., Sarkis, J., Lai, K. H.: Green supply chain management implications for "closing the loop". Transportation Research Part E: Logistics and Transportation Review, 44(1), 1-18 (2008).

19. Govindan, K., Soleimani, H., Kannan, D.: Reverse logistics and closed-loop supply chain: A comprehensive review to explore the future. European Journal of Operational Re-search, 240(3), 603-626 (2015).

20. De Angelis, R., Howard, M., Miemczyk, J.: Supply chain management and the circular economy: towards the circular supply chain. Production Planning \& Control, 29(6), 425-437 (2018).

21. Ene, S., Öztürk, N.: Open loop reverse supply chain network design. Procedia-Social and Behavioral Sciences, 109, 1110-1115 (2014).

22. Kalverkamp, M., Pehlken, A., Wuest, T.: Cascade use and the management of product lifecycles. Sustainability, 9(9), 1540 (2017).

23. Sarkis, J., Zhu, H.: Information technology and systems in China's circular economy: Impli-cations for sustainability. Journal of Systems and Information Technology, 10(3), 202-217 (2008).

24. Ghisellini, P., Cialani, C., Ulgiati, S.: A review on circular economy: the expected transition to a balanced interplay of environmental and economic systems. Journal of Cleaner produc-tion, 114, 11-32 (2016).

25. Koh, S. L., Gunasekaran, A., Morris, J., Obayi, R., Ebrahimi, S. M.: Conceptualizing a circular framework of supply chain resource sustainability. International Journal of Operations \& Production Management, 37(10), 1520-1540 (2017).

26. Urbinati, A., Chiaroni, D., Chiesa, V.: Towards a new taxonomy of circular economy business models. Journal of Cleaner Production, 168, 487-498 (2017).

27. Lüdeke-Freund, F., Gold, S., Bocken, N. M.: A review and typology of circular economy business model patterns. Journal of Industrial Ecology, 23(1), 36-61 (2019).

28. Zucchella, A., Previtali, P.: Circular business models for sustainable development: A "waste is food" restorative ecosystem. Business Strategy and the Environment DOI: 10.1002/bse.2216 (2018). 